\title{
A STUDY OF ESTIMATION OF SERUM URIC ACID LEVEL IN PATIENTS WITH PSORIASIS
}

\author{
Shanmugasundaram $V^{1}$, Nithya $D^{2}$, Sunu Joseph ${ }^{3}$, Akilandeswari $P^{4}$ \\ ${ }_{1}^{1}$ Associate Professor, Department of Dermatology, Karpagam Faculty of Medical Sciences \& Research, Coimbatore. \\ ${ }^{2}$ Assistant Professor, Department of Dermatology, Karpagam Faculty of Medical Sciences \& Research, Coimbatore. \\ ${ }^{3}$ Senior Resident, Department of Dermatology, Karpagam Faculty of Medical Sciences \& Research, Coimbatore. \\ ${ }_{4}^{4}$ PhD Research Scholar, Department of Microbiology, Karpagam Academy of Higher Education, Coimbatore.
}

\section{ABSTRACT}

Psoriasis is a disease characterized by increased epidermal cell turnover and hence an increase in purine catabolism. The serum uric acid levels in psoriasis are expected to be raised because of the high purine catabolism.

AIM

To study the levels of serum uric acid in 25 cases of uncomplicated chronic plaque type psoriasis.

\section{MATERIALS AND METHODS}

Twenty five consecutive patients with chronic plaque type psoriasis attending the Dermatology OPD of a Tertiary Care Hospital were selected and their serum uric acid levels were estimated.

\section{RESULTS}

The average uric acid levels in males psoriatic patients was between $3.6-7.7 \mathrm{mg} / \mathrm{dl}$ and in the female psoriasis patients, the serum uric acid values were between $2.5-6.8 \mathrm{mg} / \mathrm{dl}$.

\section{DISCUSSION}

The serum levels of uric acid in uncomplicated chronic plaque type psoriasis were within the normal ranges for both male and female patients. Since only chronic plaque type psoriasis patients were included in the study and the severity of disease is less in such patients when compared to erythrodermic or unstable psoriasis, the serum uric levels were observed to be within the normal ranges.

\section{CONCLUSION}

This study concludes that the serum uric acid levels are not raised in chronic plaque type psoriasis, patients with less disease severity.

\section{KEYWORDS}

Chronic Plaque Type Psoriasis, Serum Uric Acid, Purine Catabolism, Accelerated Epidermal Kinetics.

HOW TO CITE THIS ARTICLE: Shanmugasundaram V, Nithya D, Joseph S, et al. A study of estimation of serum uric acid level in patients with psoriasis. J. Evolution Med. Dent. Sci. 2016;5(12):506-508, DOI: 10.14260/jemds/2016/116

\section{INTRODUCTION}

Psoriasis is an immune mediated papulosquamous disorder with accelerated epidermal pkinetics. Psoriasis is a common, chronic disease of the skin and both genetic and environmental factors play a critical role in its inducement.[1] Recently, it was noted that elevated serum levels of uric acid are associated with factors that contribute to metabolic syndrome including hypertriglyceridemia, obesity, hypertension and diabetes. $[2,3,4,5]$ The cell proliferation index is increased; the cell transit time is shortened, leading to a high cell turnover state. It is expected that such high cell turnovers will be associated with an increase in the serum uric acid. In recent times, there is much interest in the raised levels of serum uric acid in psoriasis patients with some studies even linking it to increased incidence of psoriatic arthritis and increased prevalence of metabolic syndrome.

Financial or Other, Competing Interest: None.

Submission 13-01-2016, Peer Review 24-01-2016,

Acceptance 27-01-2016, Published 10-02-2016.

Corresponding Author:

Dr. Shanmugasundaram V,

411, G. V. Residency, Sowripalayam,

Coimbatore 641028.

E-mail: shanmugammd@yahoo.com

DOI: $10.14260 /$ jemds $/ 2016 / 116$
Some studies even go on to state that raised serum uric acid levels contributes to metabolic syndrome, which in turn may be connected to immunological abnormalities and that psoriasis may be considered as an immune-metabolic disease.[6] Since there are not many studies on the relationship between serum uric acid and psoriasis we conducted this study to estimate the levels of serum uric acid in chronic plaque type psoriasis patients.

\section{MATERIALS AND METHODS}

Twenty five consecutive psoriatic patients with chronic plaque type psoriasis irrespective of the duration of their disease were selected amongst the patients attending the Dermatology OPD in a Tertiary Care Hospital. The patients with renal diseases, gout and malignancy and on drugs lowering uric acid level like allopurinol, colchicine and febuxostat were excluded from the study. All the patients were thoroughly examined to note the areas of involvement and extent of the disease. Also patients with psoriatic erythroderma, generalized pustular psoriasis, palmoplantar psoriasis and psoriatic arthritis were not included in the study, since this study is aimed at estimating the uric acid levels only in the chronic plaque type of psoriasis. After obtaining informed consent, blood was drawn for serum uric acid estimation.

The estimation was done using fully automated clinical chemistry analyzer. ${ }^{[7]}$ The results were reported in $\mathrm{mg} / \mathrm{dL}$. 


\section{RESULTS}

The range of serum uric acid levels for 25 patients included in the study was between $3.6-7.9 \mathrm{mg} / \mathrm{dl}$, among the 25 patients, there were 16 males and 9 females. The range of serum uric acid in the male patients was between $3.6-7.9 \mathrm{mg} / \mathrm{dl}$ (Table 1 ). The range of serum uric acid in the female patients was 3.8-6.4 (Table 2). The age wise distribution, minimum/maximum and average uric acid levels in patients with chronic plaque type psoriasis are presented in Table 4 and 5.

\section{DISCUSSION}

In our study, the serum uric acid levels of all patients except one male patient was well within the normal range of 3.6-7.7 (For male) and 2.5-6.8 (For females). Compared to female patients, the serum uric acid levels in male patients was higher. This is expected as it is a normal physiological variation to find higher uric acid levels in males when compared to female.

In majority of the patients (i.e.) in $75 \%$ of the patients the serum uric acid was within the lower and middle limits of the normal, (i.e.) it was between $3-6 \mathrm{mg} / \mathrm{dl}$. In the rest of the patients $(25 \%)$, the serum uric acid was between $6-7 \mathrm{mg} / \mathrm{dl}$ which can be considered to be normal to higher or higher limits.

The average value of serum uric acid levels in male was $5.32 \mathrm{mg} / \mathrm{dl}$ and in females it was $5.18 \mathrm{mg} / \mathrm{dl}$, which is in midranges of serum uric levels. Our study is in concordance with that of little et al. (1975). ${ }^{[8]}$ whose study showed that the serum uric acid levels in patients with severe psoriasis was found to be in the middle of their normal range.

But the result of our study is in contrary to that reported by Lambert et al. and Wright (1977).[9] and Isha et al. (2011).[10] reported larger prevalence of values above the normal range in male with psoriatic arthritis uncontrolled by medications (13-15\%). Moreover in the study by Isha et al.[10] the serum uric acid in their patients was found to be more than $10 \mathrm{mg} / \mathrm{dl}$.

Herrman et al. (1930).[11] reported levels of uric acid above the upper limit of normal in 44 of 140 patients with psoriasis. Especially in those with arthritis, similar association was seen by Choi et al. (2004).[12]

As stated earlier the serum uric acid levels were found be normal in all but one, most likely because this study was conducted among patients with less severity of diseases in the outpatient set-up, besides only chronic plaque type psoriasis were included, no erythrodermic or generalized pustular psoriasis were included in the study. Psoriasis is a disease with rapid epidermal cell turnover, which in turn results in hyperuricemia.[13] Furthermore, in hyperuricemia patients, there is an increase in purine catabolism. The serum uric acid levels are exacerbated by in the severity and duration of psoriasis.[1]

The severity of the diseases in chronic plaque psoriasis is less when compared to erythrodermic pustular psoriasis due to lower body surface area involvement. Hence, this may explain the normal levels of serum uric acid in the study.

\section{CONCLUSION}

This study concludes that the serum uric acid levels are not increased in all psoriatic patients. In patients with less severe disease such as uncomplicated chronic plaque type psoriasis, the serum uric acid level was well within the normal range.

\begin{tabular}{|c|c|c|}
\hline \multirow{2}{*}{ Sl. No. } & \multicolumn{2}{|c|}{ Uric acid level in serum (Male) } \\
\hline & Age & $\mathrm{mg} / \mathrm{dL}$ \\
\hline 1 & 45 & 3.9 \\
\hline 2 & 60 & 4.7 \\
\hline 3 & 50 & 3.6 \\
\hline 4 & 45 & 7.0 \\
\hline 5 & 63 & 6.2 \\
\hline 6 & 62 & 3.8 \\
\hline 7 & 60 & 7.6 \\
\hline 8 & 69 & 4.1 \\
\hline 9 & 41 & 3.6 \\
\hline 10 & 38 & 7.1 \\
\hline 11 & 49 & 4.1 \\
\hline 12 & 49 & 7.9 \\
\hline 13 & 60 & 6.8 \\
\hline 14 & 26 & 5.8 \\
\hline 15 & 30 & 4.8 \\
\hline 16 & 46 & 3.7 \\
\hline
\end{tabular}

\begin{tabular}{|c|c|c|}
\hline \multirow{2}{*}{ S1. No. } & \multicolumn{2}{|c|}{$\begin{array}{c}\text { Uric acid level in } \\
\text { serum (Female) }\end{array}$} \\
\cline { 2 - 3 } & Age & mg/dL \\
\hline 1 & 60 & 3.8 \\
\hline 2 & 62 & 4.1 \\
\hline 3 & 30 & 4.8 \\
\hline 4 & 18 & 6.2 \\
\hline 5 & 50 & 5.8 \\
\hline 6 & 49 & 4.9 \\
\hline 7 & 68 & 5.1 \\
\hline 8 & 54 & 6.4 \\
\hline 9 & 41 & 5.7 \\
\hline \multicolumn{2}{|c|}{ Table 2: Serum uric acid level in } \\
psoriatic female patients \\
\hline
\end{tabular}

\begin{tabular}{|c|c|c|}
\hline Sex & $\begin{array}{c}\text { No. of } \\
\text { Patients }\end{array}$ & $\begin{array}{c}\text { Percentage } \\
(\%)\end{array}$ \\
\hline Male & 16 & 64 \\
\hline Female & 9 & 36 \\
\hline Total & 25 & 100 \\
\hline Table 3: Gender wise distribution of psoriasis patients \\
enrolled in this study (n=25)
\end{tabular}

\begin{tabular}{|c|c|c|c|c|}
\hline $\begin{array}{c}\text { Study } \\
\text { Group }\end{array}$ & $\mathbf{> 1 8}$ & $\mathbf{1 9 - 3 0}$ & $\mathbf{3 1 - 5 0}$ & $>\mathbf{5 0}$ \\
\hline Male & 0 & 2 & 8 & 6 \\
\hline Female & 1 & 1 & 4 & 3 \\
\hline Total & $\begin{array}{c}1 \\
(4 \%)\end{array}$ & $\mathbf{3}(12 \%)$ & $\begin{array}{c}12 \\
(48 \%)\end{array}$ & $\begin{array}{c}9 \\
(36 \%)\end{array}$ \\
\hline \multicolumn{6}{|c|}{ Table 4: Age wise distribution of psoriasis } \\
patients enrolled in this study (n=25) \\
\hline
\end{tabular}

\begin{tabular}{|c|c|c|c|}
\hline $\begin{array}{c}\text { Study } \\
\text { Group }\end{array}$ & $\begin{array}{c}\text { Minimum } \\
\text { value of } \\
\text { serum uric } \\
\text { acid (mg/L) }\end{array}$ & $\begin{array}{c}\text { Maximum } \\
\text { value of } \\
\text { serum uric } \\
\text { acid (mg/L) }\end{array}$ & $\begin{array}{c}\text { Average } \\
\text { value of } \\
\text { serum uric } \\
\text { acid (mg/L) }\end{array}$ \\
\hline Male & 3.6 & 7.9 & 5.322 \\
\hline Female & 3.8 & 6.4 & 5.181 \\
\hline \multicolumn{3}{|c|}{} & $\begin{array}{c}\text { Table 5: Uric acid value in } \\
\text { psoriasis patients in this study (n=25) }\end{array}$ \\
\hline
\end{tabular}




\section{REFERENCES}

1. Maryam G, Amir HE, Arash D, et al. Serum uric acid levels in patients with psoriasis. TUMJ 2012;70:58-63. Feig DI, Kang DH, Johnson RJ, et al. Uric acid and cardiovascular risk. N Engl J Med 2008;359:1811-1821.

2. Ishizaka N, Ishizaka Y, Toda E, et al. Association between serum uric acid, metabolic syndrome and carotid atherosclerosis in Japanese individual. Arterioscler Thromb Vasc Biol 2005;25:1038-1044.

3. Gonzalez-Gay MA, Gonzalez-Juanatey C, VazquezRodriguez TR, et al. Asymptomatic hyperuricemia and serum uric acid concentration correlate with subclinical atherosclerosis in psoriatic arthritis patients without clinically evident cardiovascular disease. Semin Arthritis Rheum 2009;39:157-162.

4. Yoo TW, Sung KC, Shin HS, et al. Relationship between serum uric acid concentration and insulin resistance and metabolic syndrome. Circ J 2005;69:928-933.

5. Agnieszka G, Aldona P, Jacek CS, et al. Biochemical markers of psoriasis as a metabolic disease. Folia Histochemica Et Cytobiologica 2012;50:155-170.
6. Trivedi RC, Rebar L, Berka ES, et al. Uric acid enzymatic method. ClinChem 1978;14:1908-1912.

7. Little H, Harvie JN, Lester RS, et al. Psoriatic arthritis in severe psoriasis. Canadian Medical Association Journal 1975;112:317-319.

8. Lambert JR, Wright V. Serum uric acid levels in psoriatic arthritis. Ann Rheum Dis 1977;36(3):264-267.

9. Isha, Jain VK, Harbans Lal, et al. C-reactive protein and uric acid levels in patients with psoriasis. Indian J Clin Biochem. 2011;26(3):309-311. doi: 10.1007/s12291-011-0132-4.

10. Herrmann F. Harnsaureuntersuchungenbei Psoriasis. Archiv fur Dermatologie and syphilis 1930;161:114-126.

11. Choi HK, Atkinson K, Karlson EW, et al. Purine rich foods and the risk of gout in men. N Eng J Med 2004;350:10931103. doi: 10.1056/NEJMoa035700.

12. Steinberg AG, Becker SW, Fitzpatrick TB, et al. A genetic and statistical study of psoriasis. American Journal of Human Genetics 1951;3:267-281. 